Bangladesh J. Zool. 40(2): 183-188, 2012

\title{
ALTERATION OF HAEMATOLOCIAL PARAMETERS OF "ZEOL FISH"- CLARIAS BATRACHUS EXPOSED TO MALATHION
}

\author{
Akhtarunnessa Chowdhury and Masudul Haq \\ Department of Zoology, University of Dhaka, Dhaka-1000, Bangladesh
}

\begin{abstract}
Clarias batrachus, locally called zeol fish, reared in fresh water on protein diet were exposed to $5 \%(8.77 \mathrm{mg} / 1$ active ingredient) and $10 \%(17.74 \mathrm{mg} / 1$ active ingredient) concentrations of malathion at $24 \mathrm{~h}$ intervals, for three weeks in cement tanks containing 580 liters of water with a constant flow (1.5/1 $\mathrm{min})$ of aerated dechlorinated tap water with no recirculation under natural light. Weekly two cc venous blood was drawn from each sample to determine the haematolocial parameters using EDTA (ethylenediamine tetraacetic acid) as an anticoagulant. The findings of this study showed that malathion in different concentrations have some diverse effects on the haematological parameters of Clarias batrachus. Exposer to $10 \%$ concentration of malathion was found to have a lethal effect on $\mathrm{RBC}$, thrombocyte, neutrophil and $\mathrm{Hb}$ concentration which caused death of the fish with the sign of hypochromic microcytic anemia. Exposer to 5\% concentration, on the other hand, showed leucopoenia due to decreased leucocyte counts. Haemoglobin $(\mathrm{Hb})$ concentrations and values of mean corpuscular haemoglobin $(\mathrm{MCH})$, mean corpuscular haemoglobin concentration (MCHC), mean corpuscular volume (MCV) and differential count of WBC levels showed decreased values at $5 \%$ concentration of malathion. Significant decrease $(\mathrm{P}<0.05)$ in $\mathrm{Hb}$ and concentration and $\mathrm{MCH}$ were observed during the exposer to the pesticide malathion. No significant difference $(\mathrm{P}>0.05)$ was observed in the levels of $\mathrm{RBC}$, MCHC, PCV, MCV and WBC.
\end{abstract}

Key words: Zeol Fish, Clarias batrachus, malathion, haematology, anemia and leucopoenia.

\section{INTRODUCTION}

Synthetic carbaryal insecticides like sevin, pyrethroid insecticides cypermethrin, deltamethrin, fevalerate and sumithion are used to protect many fruits, vegetable, pulses and field crops against a wide spectrum of fungal diseases and pests. They are also used for seed treatment of cereal grains, cotton, tomatoes etc., for the control of undesirable insects in order to increase agricultural production and in fish culture for the eradication of unwanted insects grown as a result of fertilizer used in aquatic media. According to Armella et al. (1987) those insecticides have harmful effects on aquatic environment and organisms.

Haematological parameters reflect the state of fish under stress more quickly than other commonly measured parameters, as they respond quickly to changes in environmental conditions (Alkinson and Judd 1978, Haque et al. 2006). For monitoring stress responses, predicting systematic relationships and the physiological adaptations of animals, haematological parameters have been 
widely used for the description of general health of fish (Blaxhall 1972). Haematological alterations in some fish exposed to various toxicants, viz. Cyprinus carpio to cypermethrin and fenvalerate (Mughal et al. 1993), Tilapia mossambica to cadmium chloride (Aziz and Shakoori1993), Cenopharyngodon idella to fenvalerate (Mughal et al. 1993) and Heteropneustis fossilis to deltamethrin (Kumar et al. 1999) have been investigated.

Malathion kills a wide range of non target species and extremely toxic to bees, moderately toxic to bird species and moderately to highly toxic to aquatic organisms including fish. Its leaching properties can contaminate the ground water as well as pond water. Malathion and its oxygen analog malaoxon both are carcinogenic and have been linked with increased incidence of leukemia in mammals. Malathion's chronic health hazards include suspected mutagen and teratogen, delayed neurotoxin, allergic reactions, behavioral changes, ulcer, eye damage, abnormal brain waves and immuno-suppression.

Clarias batrachus a potential cultivable fish with high economic and nutritional values needs relevant information about different culture procedures. So, present investigation aims to determine the effects of malathion on the haematological parameters of $C$. batrachus in order to monitor the general health of the fish species.

\section{MATERIAL AND METHODS}

A group of 30 fishes with an average weight of $140 \pm 14 \mathrm{~g}$, reared in natural pond water at a fish farm, located at Gazipur, Dhaka were transferred to aquarium fish rearing facility at zoological garden of Dhaka university. They were acclimatized for a week during April 2000. The fish were exposed to 5\% $(8.77 \mathrm{mg} / 1$ active ingredient) and $10 \%$ (17.74 $\mathrm{mg} / 1$ active ingredient) concentrations of malathion at $24 \mathrm{~h}$ intervals, for three weeks in rectangular glass tanks $(100 \mathrm{cc} \times 100 \mathrm{~cm})$ containing 580 liter water with constant pump aerated flow $(1.5 / 1 \mathrm{~min})$ of dechlorinated tap water with no recirculation under natural light. Ten fishes were placed in each two treatment tanks and rest 10 were treated as control without exposure to malathion.

The temperature range, dissolved oxygen, $\mathrm{pH}$ levels and total hardness, $\mathrm{CaCo}_{3}$ were record as $18.5-32^{\circ} \mathrm{C}, 8-9 \mathrm{ppm}, 7.8$ and $102 \mathrm{mg}$, respectively. During the period the fishes were on protein diet $(75 \%$ fish meal $+10 \%$ rice barn $+10 \%$ oil cake $+5 \%$ vitamins).

The treatment of $10 \%$ malathion could not be completed due to the death of all the fishes within two days. At the end of each week, four fishes from $5 \%$ malathion exposure tank and four fishes from control tanks were taken out for 
blood collection and released again into the tanks. Collection was done following Shakoori et al. (1996).

Approximately two cc venous blood using EDTA (ethylene diaminete traacetic acid) as anticoagulant was drawn from each sample for the estimation of haematological parameters, viz. Red Blood Cell (RBC) count, Total White Blood Cell (WBC) count and Haemoblobin ( $\mathrm{Hb})$ concentration. For the estimation of the above parameters the Packed Cell Volume (PVC) method described by Blaxahall and Daisley (1978) was followed. The erythrocytic characteristic like values of mean corpuscular haemoglobin $(\mathrm{MCH})$, mean corpuscular haemoglobin concentration (MCHC), mean corpuscular volume (MCV) were calculated according to Reddy and Bashamohideen (1989). The results are presented as means \pm SD. Difference between parameters were analyzed by one way analysis of variance (ANOVA), and significant means were subjected to a multiple comparison test (Duncan's Multiple Range Test) at $\mathrm{P}=0.05$ level.

\section{RESULTS AND DISCUSSION}

The blood parameter values, namely $\mathrm{Hb}, \mathrm{MCH}, \mathrm{MCV}, \mathrm{PCV}$ and $\mathrm{WBC}$ counts showed decreasing trend and $\mathrm{RBC}$ count showed mild increasing trend after exposure to man-made organophosphate anticholinesterase, non-systemic wide spectrum insecticide malathion (Table 1). No significant $(\mathrm{P}>0.05)$ changes were observed in the estimated parameters of the control fish. A significant $(\mathrm{P}<0.05)$ decrease in $\mathrm{Hb}$ concentration $(\mathrm{F}=5.16)$ and $\mathrm{MCH}(\mathrm{F}=3.89)$ were observed in the fish samples exposed to $5 \%$ malathion, which is incisive of normochromic anemia. No significant $(\mathrm{P}>0.05)$ difference was observed in the counts of RBC $(\mathrm{F}$ $=1.22), \mathrm{WBC}(\mathrm{F}=2.09), \mathrm{PCV}(\mathrm{F}=1.45), \mathrm{MCV}(\mathrm{F}=2.40)$ and $\mathrm{MCHC}(\mathrm{F}=1.41)$.

RBC count without significant differences contradicts with the findings of Oonchorynchis mykiss exposed to cypermethrin (Shakoori 1996); Cenopharyngodon idella exposed to fenvalerate and Heteropneustis fossilis exposed to deltamethrin (Kumar et al. 1999). On the other hand Koundinya and Ramamurthi (1979) reported decline in RBC of Oreochromis mossombica after exposure to sumithion and sevin. Reddy and Bashamohideen (1989) observed decreased RBC count in Cyprinus carpio after $48 \mathrm{~h}$ exposure to cypermethrin; and Santakumar et al. (1999) in Anabas testudineus exposed to azodir.

Significant decrease in $\mathrm{Hb}$ concentration after exposure to $5 \%$ malathion, may be due to impaired oxygen supply to various tissues, resulting in slow metabolic rate and low energy production (Ahmad et al. 1955), or may be due to increased in metabolic rate, which may have led to decrease $\mathrm{Hb}$ concentration level (Reddy and Bashamohideen 1989). Decreased Hb concentration level in 


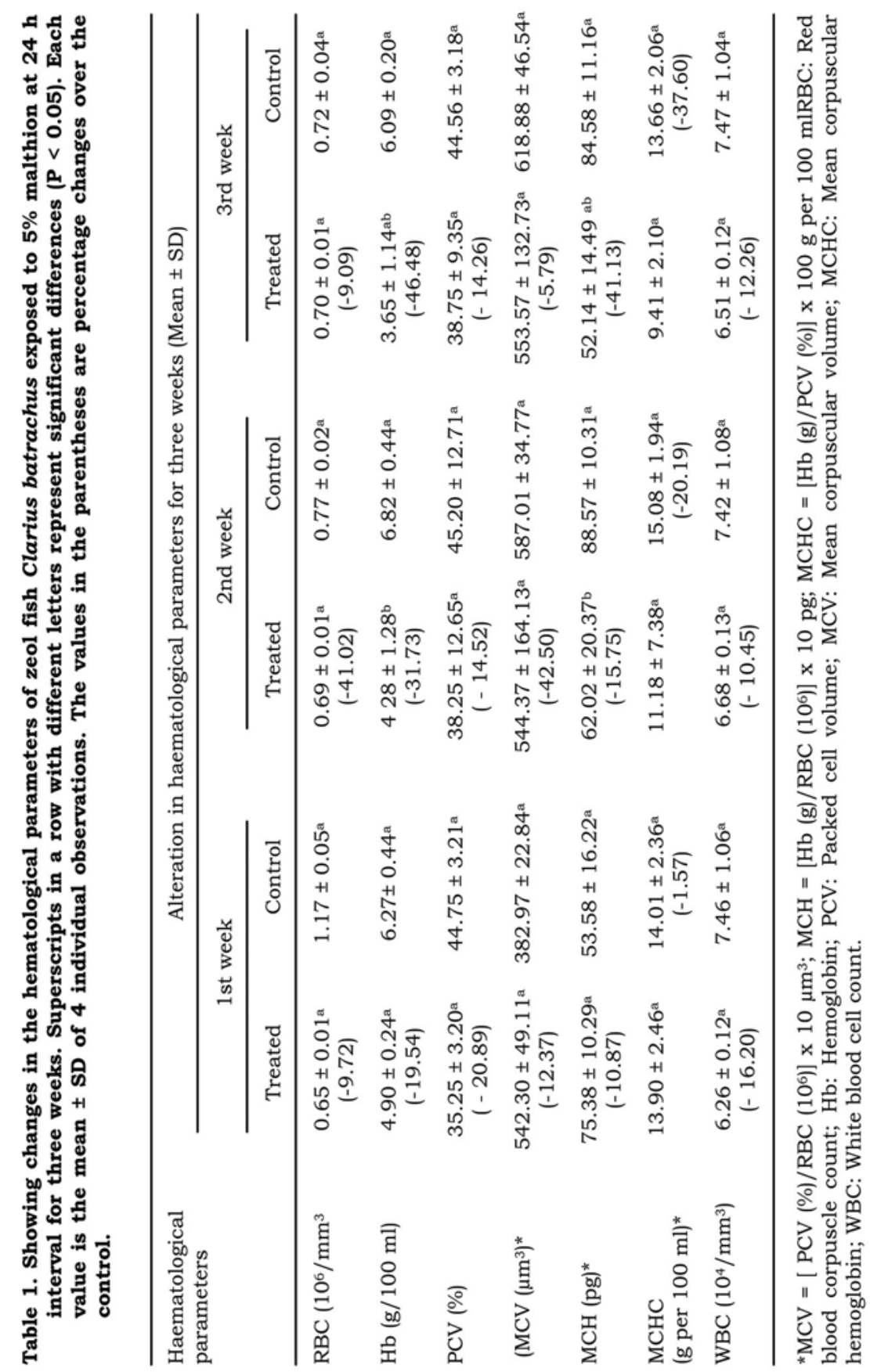


various fishes exposed to insecticides was reported, viz. Heteropneustis fossilis exposed to deltamethrin (Kumar et al. 1999); Channa punctatus to malathion (Pendey et al. 1981) and Anabas testudineus to metasystox (Natarajan 1981).

Malathion exposure of $C$. batrachus during the present investigation showed no significant decline in packed cell valume (PCV), but decline in PCV value was observed in danitol and fenvalerate treated Cenopharyngodon idella (Shakoori et al. 1996) and malathion exposed to C. puctatus (Pendey et al. 1981, and Geol and Garg 1980), whereas, the increased value of PCV was recorded in Tilapia mossambica exposed to cadmium chloride (Aziz and Shakoori 1993).

In spite of decrease in RBC count, a decline in PCV may show the extent of shrinking cell size due to insecticide intoxication ( Ahmad et al.1995). Decline PCV and MCV values in malathion treated C. batrachus might have interfered with the normal physiology of RBC which ultimately leads an anemic condition of the fish. RBC indices like MCV and MCHC declined during prolonged exposure to malathion. The same results were recorded in C. punctatus treated with metasystox (Natarajan 1981); with 2,3,4-tetraminazo-benzine methyle parathion and dinicthonate (Anees 1978). A significant decline in $\mathrm{MCH}(\mathrm{F}=3.89$; $\mathrm{P}<0.05)$ along with $\mathrm{MCV}$ and MCHC levels are indicative of hypochromic microcytic anemia. Which is in lieu with domino effect of fenvalerate treated Cenopharyngodon idella (Shakoori et al.1996).

In the present investigation decrease in WBC count contradicts with the significant increase in leucocyte count in cardmium exposed Anabas testudineus (Saravanan and Natarajan 1991). Bimodal respiration in metasystox treated Channa striatus with leucocytosis was reported by Natarajan (1981).

Significant alteration in the haemotological parameters of malathion treated C. batrachus results in hypochromic microcytic anemia and leucopenia, which are the prerequisite of immune failure and impaired growth with high mortality. Therefore, use of insecticide in cropland and in aquaculture for the eradication of unwanted insects should be restricted to prevent possible contamination by leaching into the aquatic environment to save and protect the non target aquatic organisms from these kind of toxicity.

\section{LITERATURE CITED}

AHMAD, F., ALI, S.S. and SHAKOORI, A. 1995. Sublethal effects of Danitol (Fenpropathrin), a synthetic pyrethroid, on freshwater Chinese grass carp, Ctenopharyngodon idella. Folia. Biol. (Krakow) 43: 151-159.

ALKINSON, J. and JUDD, F.W. 1978. Comparative hematology of Lepomis microlophus and Chiclasoma cyanoguttarum. Copeia 12: 230-237. 
ANEES, M.A. 1978. Hematological abnormalities in a freshwater teleost,Channa punctatus (Bloh) exposed to sublethal and chronic levels of three organophosphorus insecticides, Int. J. Ecol. Environ. Sci. 4(1 \& 2): 53-60.

ARMELlA, B.S., FRANCELYNE, M., XAVIER, R., MONIQUE, A. and SIMON, P. 1987. Effect of deltamethrin and its commercial formulation Deics on different cell types in vitro, cytotoxicity, cellular binding and intercellular localization. Pest. Biochem. Physiol. 38:103-113

AZIZ, F., AMIN, M. and SHAKOORI, A.R.1993. Toxic effects of cadmium chloride on the haematology of fish, Tilapia mossambica. Proc. Pak. Congr. Zool. 13: 141-154.

BLAXHALL, P.C. and DAISLEY, K.W. 1973. Routine haematological methods for use with fish blood. J. Fish Biol. 5: 771-781.

BLAXHALL, P.C. 1972. The haematological assessment of the health of freshwater fish: A review of selected literature. J. Fish Biol. 4: 593-604.

GOEL, K.A. and GARG, V. 1980. 2,3,4-Tetraminazobenzine-induced Hemet-biochemical anomalies in fish (Channa punctatus). Bull. Environ. Contam. Toxicol. 25(1):136-140

GHOSH, K. and BANERJEE, V. 1992. Effect of deltamethrin on hemopoietic tissue and some blood parameters of Heteropneustes fossilis. J. Freshw. Biol. 4: 283-288

KOUNDINYA, P.R. and RAMAMURTHI, R. 1979. Haematological studies in Tilapia mossambica exposed to lethal concentration of sumithion and sevin. Curr. Sci. 48: 877-879.

KUMAR, S., LATA, S. and GOPAL, K. 1999. Deltamethrin induced physiological changes in freshwater catfish Heteropneustes fossilis. Bull. Environ. Contam. Toxicol. 62: 254-258.

LONE, K.P. and JAVAID, M.Y. 1976. Effect of sublethal doses of three organophosphate insecticides on the hematology of Channa punctatus (Bloch). Pak. J. Zool. 8(1): 77-84.

LONE, K.P. and JAVAID, M.Y. 1976. Effect of sublethal doses of DDT and dieldrin on the blood of Channa punctatus (Bloch). Pak. J. Zool. 8(2):146-149.

MUGHAL, A.L., IQBAL, M.J. and SHAKOORI, A.R. 1993. Toxicity of short term exposure of sublethal doses of a synthetic pyrethroid, fenvalerate, on the chinese grass carp, Ctenopharyngodon idella. Proc. Sem. Aqua. Dev. Pak. 5: 49-74.

NATRAJAN, G.M. 1981. Effect of lethal (LC50/48 h) concentration of metasystox on selected oxidative enzymes, tissue respiration and histology of gill of the freshwater air breathing fish Channa striatus (Bleeker). Curr. Sci. 50: 985-989.

PANDEY, P.K., SINGH, N.K., CHOWDHURY, B.P. and THAKUR, G.K. 1981. Effect of organophosphate insecticide malathion on the hematology of Channa punctatus (Bloch). J. Inland. Fish. 13(2): 120-121.

PANDEY, B.N., SINGH, M.P. and CHANCHAL, A.K. 1985. Interspecific variations in circadian rhythms of some haematological values in three species of genus Channa and its relevance in aquaculture. Int. J. Acad. Ichthyo. 5(1\&2):125-129.

REDDY, P.M. and BASHAMOHIDEEN, M. 1989. Fenvalerate and cypermethrin induced changes in the haematological parameters of Cyprinus carpio. Acta. Hydrochim. Hydrobiol. 17: 101-107.

SANTHAKUMAR, M., BALAJI, M. and RAMUDU, K. 1999. Effect of sublethal concentrations monocrotophos on erythropoietic activity and certain hematological parameters of fish Anabas testudineus (bloch). Bull. Environ. Contam. Toxicol. 63: 379-384.

SHAKOORI, A.R., MUGHAL, A.L. and IQBAL, M.J. 1996. Effects of sublethal doses of fenvalarate (a synthetic pyrethroid) administered continuously for four weeks on the blood, liver and muscles of a freshwater fish, Ctenopharyngodon idella. Bull. Environ. Contam. Toxicol. 57: 487-494. 